\title{
Imaginary Significations and Education as a Social Institution
}

\author{
Stavros Moutsios \\ Associate Professor, International Comparative Education, Aarhus University \\ Marie Curie Research Fellow, Humboldt-Universität zu Berlin, \\ Institut für Erziehungswissenschaften, Abteilung Vergleichende Erziehungswissenschaft, Germany \\ Email:stam@dpu.dk
}

\section{Doi:10.5901/ajis.2013.v2n11p144}

\section{Abstract}

This paper is about culture and education as a social institution. Evidently, there is no society without culture and there is no society without institutions. Culture is incarnated in social institutions and we need to elucidate this relation in order to understand education across societies. By education we mean not only the official school system, but the entire realm of learning experience available in social institutions, or what we call today lifelong learning. Our analysis is based on the Castoriadian ontology, which considers culture embedded in the imaginary institution of society. Each society is instituted by creating its own world of imaginary significations and exists through them. In these terms, the paper argues, to understand education as an institution of a particular society, ones needs to access its world of significations. The paper explores further the methodological implications of this argument for social-scientific and educational research.

\section{Introduction}

This paper, part of a broader theoretical project in comparative education studies, ${ }^{1}$ examines theoretically the relation between culture and education. Based largely on the ontology of Cornelius Castoriadis (1987), we maintain, that societies have not only a functional/instrumental dimension (i.e. their physical and biological reality) but also a signitive dimension, which expresses their culture. It is comprised of a dynamic flux of meanings, or social imaginary significations, which are incarnated in objects, individuals and institutions. Education is itself one of those institutions, but at the same time, it is embedded in and it cuts across all other social institutions - that is, it is trans-institutional. After drawing these theoretical lines, the paper considers their implications for cross-cultural research in education.

\section{Culture and Social Imaginary Significations}

Kroeber and Kluchohn (1952), in their classical compilation, Culture: A Critical Review of Concepts and Definitions, collected 164 definitions of the notion of culture. Notwithstanding though the wealth of definitions and the centrality of culture in social sciences in general and comparative education in particular, culture remains a concept which is subject to debate and clarification. Denys Cuche (1996), for instance, a French ethnologist, offers in The Notion of Culture in Social Sciences an overview of culture, from its emergence in the European languages to its widespread adoption by anthropology. The term cultura, as Cuche writes, appeared around the end of the $13^{\text {th }}$ century to indicate a cultivated piece of land, and by the beginning of the $16^{\text {th }}$ century it was taken to mean the very act of cultivation. The term's metaphorical sense is formed by the middle of the $16^{\text {th }}$ century to connote the cultivation or development of a capacity. Later on culture is used in opposition to 'nature' to designate the knowledge accumulated and imparted by the mankind and the formation of human spirit. In the $18^{\text {th }}$ century culture was still used in singular, to indicate, in full accord with the ideology of progress which was celebrated by the Enlightenment, a characteristic attribute of humans. This applies also to the term 'civilisation' which is already used, in singular too, during the same period, with reference though to societal advancements in education, law and governance, whereas culture referred more to an individual state achieved mainly through education and arts. In Germany, during the $18^{\text {th }}$ century, the word Kultur is essentially a transfer of the French notion, while Zivilisation is identified largely with economic and technological advancements. However, from the $19^{\text {th }}$

\footnotetext{
1 The paper is part of a project, currently being carried out at Humboldt University in Berlin, under the EU's Marie Curie programme of Intra-European Fellowships (FP7-People-2011-IEF, CETH, 298656).
} 
century culture is framed by a national understanding: on the one hand culture is re-defined under the post-1806 current of nationalism which seeks the 'German character' and the uniqueness of the German culture; and on the other this new understanding results from the pioneering work of Johann Gottfried Herder (i.e. Ideen zur Philosophie der Geschichte der Menschheit) which identified culture with nationality, though at the same time opposed nationalism and foregrounded instead the idea of mankind as a common species organised in different nationalities and cultural forms - thus ushering in what we would call today 'cultural relativism' (Ibid, 26). Apparently, this perception as well as the fact that education from the $18^{\text {th }}$ and especially the $19^{\text {th }}$ century came under the auspices of the nation-state, had an impact on Comparative Education, as it is testified by the preoccupation of some of its prominent authors with the 'national character': Issac Kandel, Nicholas Hans, and Vernon Mallinson looked at 'national character' as the generator but also the outcome of an education system (Jones, 1971) Nicholas Hans $(1949,9-10)$ went so far as to propose factors which make an 'ideal nation' - a nation being for him 'a cultural social unit ... clearly distinguished from other 'nations".

Notwithstanding the framing of culture by the nation or by nationalism, it is important to note that from the late $19^{\text {th }}$ century, and especially in the early $20^{\text {th }}$ century, culture, now being used in plural, becomes the object of Anglo-American anthropology which gives to the term a largely descriptive definition. For example the British anthropologist Edward Tylor defines in 1871 'culture or civilisation' as 'that complex whole which includes knowledge, belief, art, law, morals, customs, and any other capabilities and habits acquired by man as a member of society' (Cited by Kroeber and Kluckhohn, 1952, 43.). The new perception continues with a host of other anthropologists since then, with notable examples: Franz Boas, who opposed culture to the notion of 'race'; Bronislaw Malinowski, a proponent of a functionalist approach to culture; and Ruth Benedict and Margaret Mead who emphasised the pedagogic role of 'cultural transmission' (Cuche, 1996). Drawing on more or less known works from anthropology Kroeber and Kluchohn (1952) cite numerous definitions on culture, which adopt a variety of angles. It is worth selecting here a few:

- A culture is any given people's way of life, as distinct from the life-ways of other peoples (p. 51).

- The culture of a people may be defined as the sum total of the material and intellectual equipment whereby they satisfy their biological and social needs and adapt themselves to their environment. (p. 56).

- Culture ... may be defined as all behavior learned by the individual in conformity with a group....(p. 58)

- Culture is the rationalization of habit (p. 60)

- Culture consists of patterned and functionally interrelated customs common to specifiable human beings composing specifiable social groups or categories. (p. 61).

- ... a culture is a definite association complex of ideas (p. 66).

- Culture is all behavior mediated by symbols (p. 69).

Castoriadis's (1993) definition of culture combines somehow the traditional French/German definition (culture as the works of the human spirit and the access of individuals to them) with the more relative and descriptive understanding of culture offered by the Anglo-American anthropology, which, as the above examples indicate, intends the entire institution of society. Culture for Castoriadis is 'everything, in the institution of society, that goes beyond its enseblisticidentitary (functional-instrumental) dimension and that the individuals of this society positively cathect as 'value' in the largest sense of the term' (ibid, 301-302). In these terms, there is no society without culture, since there is no society reduced to its functional/instrumental dimension. Apart from this dimension, or apart from the natural stratum a society leans on for its institution, there is a-meaning and chaos (in the sense of void, not disorder). But this chaos is also subject to creation, to a power of formation, or, in Latin, as it was noted above, to a vis formandi, which imposes on the chaos a cosmos, a more or less ordered world. Culture is precisely this giving of form to the chaos, namely giving meaning to a groundless world (ibid).

The meanings given by societies to their world are what Castoriadis calls social imaginary significations. We shall elaborate on this concept through his philosophy, as, notwithstanding the common talk in the social sciences today about 'imaginaries', we rarely come across precise accounts which can help sociological and cross-cultural research. For example, amongst the well-known works which look at social imaginaries are those of Benedict Anderson, Charles Taylor and to some extent of Edgar Morin. Morin (2001) recognises the importance of imagination and psychic life throughout his major work La Méthode. He regards the psyche (anima) as complementary to the mind (animus), but the former is largely missing (or is limited to the affective domain), as opposed to the later, from his theory of culture. Anderson (1983) is concerned with the nation as an 'imagined community', constructed through shared frames of interpretation, by the use of means such as print languages and media. Anderson points out that this imaginary aspect, the 'new consciousness', is what matters in understanding nation formation, rather than looking for factors such as economic interests. Nevertheless, he does not explore this aspect theoretically beyond the area of nationalism which is his focus. Taylor (2004), in his effort to identify its key forms in the Western Modernity, gives a broad definition of the social imaginary, which he differentiates 
from social theory: whereas the latter is made by a small minority, the former is the way that people in general imagine their social existence and surroundings as well as their expectations and underlying notions and images. In other words, social imaginary is 'that common understanding that makes possible common practices and a widely shared sense of legitimacy' (ibid, 23). This is a useful definition which needs however to be refined through the Castoriadian ontology, from which after all Taylor borrows the concept (Smith, 2010, 3).

Social imaginary significations do not constitute simply a world of meaning in which the new born individual is immersed, but they constitute for a society its very world. Societies should be seen in both their functional or instrumental dimension as well as their signitive dimension, the latter being indissociable from the former. A functional/instrumental dimension exists because there is a natural stratum on which the society leans on and which is subject to this kind of organisation. There are animals, stones, sun, moon, rivers and mountains, men, women and children. There is day and night, humans give birth to humans and horses to horses. There is, in other words, a biological and physical reality, the first natural stratum, which the institution of a society cannot ignore. In this natural stratum there are properties and classes that can be discerned, identified, categorised or ensembled. The world is enseblisable and thus subject to what Castoriadis calls identitary-ensemblist logic, which expresses the functional/instrumental dimension of the society: we can distinguish, choose, posit, count and speak in certain terms instead of others. But at the same time, no society can be instituted without a signitive dimension - otherwise it would be a functional/instrumental automaton. For instance, it is a natural fact that there are male and female individuals, but the way they are related and reproduced is subject to how a society 'sees' and institutes the two genders and their relations It is a natural fact that there are children, but how they are raised in different societies and different periods touches upon the given imaginary significations with regard to childhood.

Each society then is instituted by creating its own world of significations, which hold it together: they bring a sense of co-belonging to objects, acts, functions and individuals and they condition and orient what is doable and what is representable in this society. The society thus exists through the world of significations, which itself brought to existence, and immerses whatever new appears immediately into this world. In other words, every society constructs a representation of itself and, consequently, of other societies, in the past and in the present. Individuals become social individuals because they internalise the imaginary significations incarnated in social institutions; ways of thinking, rules, values, and their very identities as social beings, depend on this internalisation. Social imaginary significations have a triple role: they structure the general representations of the world; they set the types of affects characteristic for each society - its emotional relation to life; and they indicate the aims of social doing - i.e. where a society should be heading - and the hierarchy it posits on its aims. It is this representational, affective and intentional complex conveyed by imaginary significations which defines how a society 'sees' its present and its past, but also the future it is pursuing. Social imaginary significations are social because, and only if, they are shared by the anonymous collectivity; and they are imaginary because they do not derive from natural laws or rational syllogisms, but they are created by societies. However, they are real factors which indicate what is valued and what is not valued, what is worth and what is not worth for a particular society; they point to what a society regards as information, and the weight, value or importance granted to this information; and they are presentified in the institutions, projects and ultimately the history of a society. To understand, therefore, the particularity of a period one has to understand the imaginary significations created by the society (Castoriadis, 2000, 2010).

Accessing the imaginary significations of a society is something which does not follow the analytical process pertaining its identitary-enseblist dimension. Imaginary significations are related in such a complex and inter-referential manner, which makes it impossible it to reconstitute the whole set of its elements. It is only the identitary-enseblist dimension that follows the schemata present in the logico-mathematic theory of sets, i.e. elements, classes, properties, and relations, which can be distinguished, ordered, counted, arranged, re-arranged etc. This is the functional/instrumental aspect of social institutions which follows the operative schema of determinacy: something exists because it can be defined and determined. In the case of the imaginary, though, something exists as signification. Imaginary significations can be identified but not determined nor can they be reassembled or reproduced. The way they are related with each other is that of referral. For example, the signification 'priest' refers to 'church', 'church' to the 'religion', 'religion' to 'God', 'God' to 'sin', etc. Imaginary significations cannot be clearly distinct nor can they be reconstructed or recombined and thus reconstitute a particular society or epoch (Castoriadis, 2010). To describe the complex way that imaginary significations are associated Castoriadis uses the imagery of magma. In geology, magma is a flow of molten rock, volatiles and solids, a material in constant state of transition from flux to structure, formed and formless at the same time. The term signifies the fluid and dynamic character of significations, their cross-flows and interminglings, and helps understands their non-reducibility to sets and sub-sets (Smith, 2010, 12-15). In other words, magma cannot be reduced to the sum of its parts nor can be re-produced by assembling these parts. In this regard, a given society cannot be seen 
as system of distinct objects (Castoriadis, 1987, 343). To approach then the magma of imaginary singifications in any given society one has to approach its other most important creation, i.e. its institutions.

\section{Education as a Social Institution}

Imaginary significations are embodied in institutions. In Castoriadis's $(1987,132)$ definition an institution is 'a socially sanctioned symbolic network, in which a functional component and an imaginary component are combined in variable proportions and relations'. The symbolic is important in institutions but they cannot be reduced to it. To understand symbols one needs to identify the imaginary significations they convey, and by extension, institutions themselves. To put it simply, an institution is unthinkable without signification. Social imaginary significations are incarnated in institutions, and first and foremost in the two major social institutions, manifestations of the functional/instrumental (or identitary/ensemblistic) dimension of society: that of teukhein (i.e. techniques, technologies, tools, etc. - the instrumental/functional aspect of 'social doing'); and that of legein (i.e. language - the instrumental/functional aspect of 'social representing/saying'). Indeed, language is not merely a 'tool of communication' but one of the most important institutions that a society creates, in which the individual is immersed from the start of his/her life. Notwithstanding universal and invariant structures across languages, the latter convey also a semantic part, which embodies the imaginary significations of particular societies. In Castoriadis's terms, language embodies a code, an identitary or univocal dimension, which is constituted in a system of ensemblisable relations (e.g. grammatical classes or syntactical types); but, it is also langue ( $\varphi$ átı $\zeta$ ), namely, it includes a signitive dimension which refers to the magma of imaginary significations available in the society (ibid, 237-244). Institutions are also, for example, economy, political organisation, family, or the individual itself, as societies fabricate, in different periods, different types of individuals.

The latter are what the author calls second-order institutions. The first or primal institution of society is the very fact that society itself creates itself as society, by creating institutions incarnating imaginary significations specific to it. This first institution is articulated through second-order institutions. Second-order does not mean secondary; it means that these institutions are held together by the primal institution of the society which embodies its central significations. It is not a relation of priority, but of reliance, in the sense that one cannot exist without other. Castoriadis (2007) divides them into two categories: transhistorical institutions, and those which are specific to particular societies. Transhistorical institutions are, for example, language, the individual and the family - institutions which exist across history and societies, no matter what content they give to them. In other words, there is no society without language; all societies institute some type of individual (i.e. what a man, a woman or a child means for them); and all societies have in place some form of family, whatever this may be, to assure reproduction and socialisation of the new generation. Second-order institutions specific to given societies are absolutely essential for them as they convey its particular imaginary significations. For example without the polis Greek antiquity would be inconceivable; and without the business enterprise, there is no capitalism. Moreover, one has to take into account the interaction of institutions. To access the concrete texture of a society one has to consider the way the transhistorical and society-specific institutions are interwoven. In addition, institutions are connected to its other in numerous ways, so that changes in one of them have repercussions to other institutions (e.g. the dislocation of the traditional roles and relations between men and women have effects on education and labour markets).

Education is also of course an institution, which should not be identified only with the state education system, established since the European Modernity. This identification is in fact typical in the writings of the neo-institutionalist authors (e.g. Meyer, 1977), but also in most Comparative Education tradition. The study of education within and across cultures should take into account that education is a lifelong and life-wide process, to use today's terminology. Namely, education is embedded in the very institution of society; i.e. it is present not only in designated institutions, but it expands across all life sectors. This was common knowledge already in Ancient Greece (hence Simonides's line 'the polis teaches

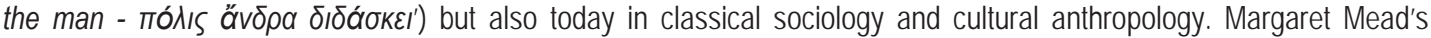
influential studies, for example, in New Guinea tribes in the 1930s, demonstrated the pedagogic role of social institutions in sexuality and gender formation (Mead, 1935, 2001), while today, anthropologists (e.g. Lancy et al, 2010) investigate widely children's' learning in various contexts (i.e. family, play, work, neighbourhood, streets etc.), including the impact of the old as well as the new Media. In sociology, Durkheim $(1956,71)$ has defined education also from a broad perspective ('Education is the influence exercised by adult generations on those that are not yet ready for social life...'), and thus saw its purpose (to develop the states demanded 'by both the political society as a whole and the special milieu for which [the child] is specifically destined). Durkheim (ibid) has clearly identified education with socialisation ('Education consists in the methodical socialisation of the young generation'), as do so contemporary lifelong learning scholars who can see education extended throughout adult life (e.g. Jarvis, 1983). 
Education in this regard is a second-order institution, both transhistorical (as there can be no society without some form of knowledge impartation to its young generations) as well as specific to particular societies. But if we understand education in its lifelong learning perspective, we should then distinguish its society-specific aspect, which is of the main interest in Comparative Education and related knowledge areas, in: trans-institutional education, and official education provided by designated institutions, such as the state school system. Education is trans-institutional because it takes place through and across social institutions (e.g. language, family, state, nation, church, market, elections, army, workplace, Media, etc.), by which a given society socialises its members; it may be also provided formally by designated institutions, e.g. by monasteries, by private mentors, in schools, by an enterprise, by a community, or by the state. The state education system, which has been the main object of educational comparison, and whose emergence we shall study later on in this inquiry, is the most typical form of a designated institution for education across the world during the last two centuries. Earlier, religious establishments (e.g. church, mosques and monasteries) were the main providers of official education in many parts of the world, and nowadays the market undertakes increasingly a large share of educational provision.

In short, along with imaginary singifications, institutions are sine qua non creations of human societies. Significations are embodied in both the primal or first institution of society but also in a host of second-order institutions, education being one of them. But education in a society is provided not only formally through its designated institutions (e.g. the state system), but also across institutions, namely it is trans-institutional. Thus, by approaching education as a second-order institution, in both these aspects, we access the magma of imaginary significations of the society under consideration.

\section{Conclusion: Methodological Implications}

Castoriadian ontology has serious implications for various traditions of social theory which due to limited space cannot be addressed here. We can just raise, in conclusion, two methodological points with regard to the comparative study of education as an institution.

First, the distinction between an instrumental/rational and a signitive dimension in society posits the differentiation of our methodological approaches and, by extension, it entails two different kinds of knowledge. To the identitaryenseblistic dimension, it is science (e.g. physics, cosmology or geology) that corresponds and therefore the appropriate approach here is explanation. Explanation entails the reduction of a phenomenon to its causes or to general laws. By applying this approach to society the researcher seeks to establish a coherent system characterised by determinancy and objectification, which means, as Edgar Morin (1986) puts it, that he/she conceives and studies human beings as objects. However, because humans and their activities and institutions involve also a signitive dimension, the pertinent approach to their study is understanding. Understanding intends the meaning of situations or actions experienced by individuals and social groups. With regard to the individual, as again Edgar Morin (ibid) puts it, understanding leads to an empathetic knowledge, which involves a double-bind movement: it includes a projection of the self onto the other and identification of the other with oneself, namely an ego alter becomes an alter ego. With regard to society, understanding as an approach allows the researcher to access the significations created by this society and presentified in its institutions. To look for causes behind the emergence of these significations is pointless because they are creations ex nihilo, though neither in nihilo nor cum nihilo. For this reason, as Castoriadis (2003) adds, there may be some necessary but never sufficient conditions for the emergence of significations and meanings. Thus what matters is the quest for the signitive content of social institutions, which is subject to understanding.

Second, in order to go beyond the comparison of elements falling into the identitary-enseblistic organisation of societies, we should acquire access to their world of significations, namely their particular eidos. This presuposes that we regard the foreign society as equal, and simply as another culture, rather than as inferior or superior to ours. Looking the other society as superior indicates a disposition to renounce one's own institutions and adopt the foreign ones. Viewing the other society as inferior (historically, the most common attitude), indicates the perception that one's own institutions are the only valid and should be adopted by the others. To see a society as simply other, it means that one is capable of reflecting on and questioning one's own institutions, because they allow for it; that they do not regard as meaningful only their own representation of the world; and that their effort to understand the others is not subjected to any sort of policy agenda or 'practical purpose'. In this regard, the researcher acknowledges the alterity and the singularity of the society to be considered, expressed in its instituted imaginary significations. The educational researcher acknowledges also that education is not only provided by an official system but it takes place across institutions and throughout life - something which makes the research more challenging but at the same time it opens space to make better sense of what it means 
to be educated in the society in question. For this purpose one would need to go beyond the functional/instrumental organisation of education as institution and attempt to penetrate and understand the specific magma of imaginary significations embodied in educational arrangements and pedagogic activities and relations.

\section{References}

Anderson, B. (1983) Imagined Communities: Reflections on the Origins and Spread of Nationalism. London: Verso.

Cartledge, P. (2006) Thermopylae: The Battle that changed the World. London. Macmillan

Castoriadis, C. (1987) The Imaginary Institution of Society. Cambridge:Polity Press.

Castoriadis, C. (1993) Political and Social Writings. Volume 3, 1961-1979. Translated and edited by D.A. Curtis. Minnesota: University of Minnesota Press.

Castoriadis, C. (2000) Lectures in Greece. Athens: Ypsilon/Vivia [in Greek].

Castoriadis, C. (2003) Philosophy and Science - a conversation with Georgios Evangelopoulos. Athens: Eurasia Publications [in Greek]. Castoriadis, C. (2007) Figures of the Thinkable. Stanford: Stanford University Press.

Castoriadis, C. (2010) A Society Adrift. http://www.notbored.org/ASA.pdf

Cuche, D. (1996) La Notion de Culture dans les Sciences Sociales. Paris: Editions La Decouverte. [Greek translation, 2001, Athens: Typothito].

Durkheim, E. (1956) Education and Sociology. New York: The Free Press.

Hans, N. (1949) Comparative Education: A study of Educational Factors and Traditions. London: Routledge and Kegan Paul.

Jarvis, P. (1983) Adult Education \& Lifelong Learning. Theory and Practice. Third Edition. London: Routledge Falmer.

Jones, Ph. (1971) Comparative Education: Purpose and Method. Queensland: University of Queensland Press.

Kroeber, A.L. and Kluckhohn, C. (1952) 'Culture: A Critical Review of Concepts and Definitions'. Cambridge: Harvard University Printing Office.

Lancy, D.F., Bock, J. and Gaskins, S. (2010) The Anthropology of Learning in Childhood. Walnut Creek: AltaMira Press.

Mead, M. (1935/2001) Sex and Temperament in Three Primitive Societies. New York: Perennial.

Meyer, J.W. (1977) 'The Effects of Education as an Institution'. The Americal Journal of Sociology. 83(1): 55-77.

Morin, E. (2001) La Méthode, 5: L' humanité de l' humanité. Paris: Éditions du Seuil.

Smith, K. E. (2010) Meaning, Subjectivity, Society: Making Sense of Modernity. Leiden: Brill.

Taylor, C. (2004) Modern Social Imaginaries. Durham: Duke University Press. 